\title{
DETERMINANTS OF TERRITORIAL RECRUITMENT IN BONELli'S EAGLe (AQUILA fasciata) POPULATIONS
}

\author{
antonio Hernández-Matías, ${ }^{1,7}$ Joan Real, ${ }^{1}$ Roger Pradel, ${ }^{2,3}$ Alain Ravayrol, ${ }^{4}$ \\ Nicolas Vincent-Martin, ${ }^{5}$ Fabrice Bosca, ${ }^{6}$ and Gilles Cheylan ${ }^{5}$ \\ ${ }^{1}$ Conservation Biology Group, Departament de Biologia Animal, Universitat de Barcelona, Av Diagonal 645, Barcelona 08028, Catalonia, Spain; \\ ${ }^{2}$ Centre d'Ecologie Fonctionnelle et Evolutive, Centre National de la Recherche Scientifique, 1919 route de Mende, 34293 Montpellier cedex 5, France; \\ ${ }^{3}$ Population Ecology Group, Institut Mediterrani d'Estudis Avançats (CSIC-UIB), Miquel Marques 21, Esporles 07190, Spain; \\ ${ }^{4}$ La Salsepareille, 3 bis rue Vieille commune, 34800 Clermont l'Hérault, France; \\ ${ }^{5}$ Conservatoire-Etudes des Ecosystèmes de Provence, Ecomusée de la Crau, 13310 Saint Martin de Crau, France; and \\ ${ }^{6}$ Conservatoire des Espaces Naturels du Languedoc-Roussillon, 474 allée Henri II de Montmorency, Montpellier, France
}

\begin{abstract}
Aвstract.-Recruitment is an essential component of the life history and population dynamics of bird species. We provide comprehensive information on the determinants of territorial recruitment in populations of the endangered Bonelli's Eagle (Aquila fasciata). Field work was based on a long-term study of two populations located in the northwest of this species' range, one in Catalonia (northeastern Spain) and the other in Provence and Languedoc-Roussillon (southeastern France). Nestlings were banded ( $n=451$ marked birds) and known territories were intensively monitored during the period 1980-2007. First, a global return rate of $9.97 \%$ (45 recruits) was calculated, with no significant differences between the two populations. Second, results showed that both the birth year and the breeding success of the birth territory had significant effects on recruitment probability: nestlings from territories with better breeding success were more likely to recruit. Third, seniority analyses based on capture-resighting techniques were used to estimate the agespecific probabilities that a territorial bird in a given year was inexperienced. The parameter estimates for this probability ranged from 0.985 to 0.999 for 2-year-olds and from 0.763 to 0.808 for 3-year-olds and then fell drastically to $0.066-0.272$ for 4 -year-olds and older. Fourth, females were found to disperse farther than males. Additionally, there was a significant interaction between sex and area of birth, in that females from Catalonia dispersed farther than females from France. Finally, previously occupied territories located in the highest-quality areas with the highest territorial density were found to be the most attractive to inexperienced individuals. Received 19 January 2009, accepted 16 May 2009.
\end{abstract}

Key words: Aquila fasciata, Bonelli's Eagle, Hieraaetus fasciatus, natal dispersal, raptors, seniority probability, territory selection.

\section{Determinantes del Reclutamiento Territorial en Poblaciones de Aquila fasciata}

RESUMEN.-El reclutamiento es un componente esencial de la historia de vida y de la dinámica poblacional en las aves. En el presente estudio se proporciona información detallada sobre los factores que determinan el reclutamiento territorial en una especie amenazada: Aquila fasciata. Se estudiaron dos poblaciones localizadas en el extremo noroccidental de la distribución de la especie, una en Cataluña (NE de España) y la otra en Provence y Languedoc-Roussillon (SE de Francia). La metodología de campo se basó en un estudio a largo plazo que incluyó marcaje de volantones $(n=451$ pollos) y seguimiento de territorios en ambas poblaciones durante el período comprendido entre 1980 y 2007. En primer lugar, se estimó una tasa de retorno global del 9.97 \% (45 reclutas), que no difirió significativamente entre las poblaciones estudiadas. En segundo lugar, se detectaron efectos significativos del año de nacimiento y del éxito reproductor del territorio de origen sobre la probabilidad de que un volantón fuera posteriormente reclutado: aquellos pollos de territorios con mayor éxito mostraron mayor probabilidad de reclutamiento. En tercer lugar, se utilizaron técnicas de captura-reavistamiento para estimar la probabilidad de que un individuo territorial de una determinada edad fuera un recluta. Este parámetro mostró valores entre 0.985 y 0.999 para individuos de dos años, entre 0.763 y 0.808 para individuos de tres años, y se redujo drásticamente para individuos de cuatro años o mayores, mostrando valores de ente 0.066 y 0.272 . En cuarto lugar, las hembras se dispersaron a mayor distancia que los machos. Además, las hembras de Cataluña se dispersaron a mayor distancia que las hembras de Francia. En último lugar, aquellos territorios previamente ocupados, situados en áreas con elevada densidad y situados en áreas de mayor calidad se mostraron más atractivos para individuos sin experiencia territorial previa.

7E-mail: ahernandezmatias@ub.edu

The Auk, Vol. 127, Number 1, pages 173-184. ISSN 0004-8038, electronic ISSN 1938-4254. @ 2010 by The American Ornithologists' Union. All rights reserved. Please direct all requests for permission to photocopy or reproduce article content through the University of California Press's Rights and Permissions website, http://www.ucpressjournals. com/reprintInfo.asp. DOI: 10.1525/auk.2009.09143 
RECRUITMENT, THE ENTRY of prebreeding birds into the breeding portion of the population, is an essential component of bird life histories (Newton 1989, Roff 1992), and understanding the patterns of recruitment is critical for adequately interpreting the spatial and temporal dynamics of populations (Newton 1979, Greenwood and Harvey 1982, Ferrer et al. 2004, Becker and Bradley 2007). Consequently, detailed knowledge of recruitment is important if conservation and management issues for a given species are to be tackled successfully (e.g., Ringsby et al. 2006).

The key steps to recruitment, in order, are fledging, pre-adult survival, the decision to breed in a given year and at a given site, and the ability to do so. Factors demonstrated or hypothesized to affect one or more stages of the recruitment process include individual (Korpimäki and Wiehn 1998, Sedinger and Chelgren 2007), parental (Saino et al. 1997, Tella et al. 2000), and environmental characteristics (Newton 1992, Ferrer and Penteriani 2003, Rutz and Bijlsma 2006). All these components of the recruitment process help trace a complex itinerary from birth to recruitment that is mediated by a large set of factors operating at different spatial and temporal scales (Müller et al. 2005, Becker and Bradley 2007). As a result, comprehensive approaches to the determinants of recruitment in bird species are scarce (Sharp et al. 2008), particularly in long-lived territorial species, largely because it is difficult to monitor individuals over the time and spatial spans between birth and recruitment (Kenward et al. 2002), but also because the effects of recruitment determinants may vary considerably between years and sites.

Here, we provide comprehensive information on the determinants of recruitment in two populations of Bonelli's Eagle (Aquila fasciata). This territorial accipitrid is distributed from Southeast Asia and the Middle East to the western Mediterranean (del Hoyo et al. 1992). The European Bonelli's Eagle population is estimated at $920-1,100$ pairs, of which $~ 80 \%$ occur in the Iberian Peninsula (BirdLife International 2004). This species has undergone a dramatic decline in number and range in recent decades and is now listed as endangered in the European Community Directive on the conservation of wild birds (79/409/EEC; Rocamora 1994, BirdLife International 2004, Ontiveros et al. 2004, Real 2004). Like other territorial raptors, Bonelli's Eagles pass through a transient nomadic phase, known as the "dispersal period," after postfledging dependence and before recruitment, that may last for several years (Newton 1979, Real and Mañosa 1997). Dispersing birds perform long-distance movements to dispersal areas (Cheylan et al. 1996, Real and Mañosa 2001, Cadahía et al. 2007b). Available data also show that dispersing birds suffer high mortality (Arroyo et al. 1998, Real and Mañosa 2001). However, little information exists on the return rates of recruited Bonelli's Eagles (but see Real and Mañosa 1997) or on their natal dispersal movements (Ontiveros et al. 2004), two factors that could have important consequences for the demographic dynamics of subpopulations and may influence the design of appropriate conservation measures (Soutullo et al. 2008). As in the case of most large and medium-sized raptors, the factors determining recruitment are poorly understood in this species.

To study recruitment in Bonelli's Eagles, we used data from long-term monitoring of two populations located at the northwestern limit of the species' distribution. Because our first aim was to analyze the factors affecting the key steps in the recruitment process, we primarily addressed the following topics: (1) prefledging factors affecting the probability of recruitment, (2) the effect of age on recruitment probabilities, (3) factors affecting the distance and direction of natal dispersal distance, and (4) the features that affect the attractiveness of territories to recruiting birds. Additionally, we used the data set to provide basic information on the recruitment process in this endangered species.

\section{Methods}

Study areas.-We studied two Bonelli's Eagle populations, one in Provence, Languedoc-Roussillon, and Rhône-Alpes, southeastern France (1990-2007), and the other in Catalonia, northeastern Spain (1980-2007), hereafter referred to as the "French" and "Catalan" populations, respectively. The French population is geographically isolated at the northwestern boundary of the species' distribution and consisted of 23-29 pairs during the study period. The second population is located south of the first, within the species' core distribution in the Iberian Peninsula, and consisted of about 80-85 pairs during the 1970 s, a number that decreased progressively until it stabilized at 66 pairs in 2004 (Real et al. 2004). The density of territories is lower in France (1.3 \pm 0.9 [SD] pairs within a $10-\mathrm{km}$ radius from a focal nest) than in Catalonia $(2.7 \pm 1.6)$.

Field procedures.-A long-term study based on banding and territory monitoring was conducted in both populations. Nestlings 40-50 days old were marked at the nest with an alphanumericcoded darvic band, which could be read through a telescope from $\leq 200$ m (France: 329 fledglings in 1990-2004; Catalonia: 122 fledglings in 1986-1993). Nestlings from Catalonia were also equipped with plastic wing tags that are visible in flight (see Real and Mañosa 2001). The variables recorded for nestlings were weight, body size (foot length), sex, age, and rank (based on hatching order). Not all measurements were available for all nestlings, so the sample sizes in the analyses varied somewhat. Additionally, numerous territories in both populations were monitored intensively (France: 35 territories in 1990-2007; Catalonia: 15-70 territories in 19802007). Monitoring activities included at least three visits during the breeding season, and the variables recorded in these cases were occupancy status, identity (if banded) and plumage age of territorial birds, breeding behavior, and number of fledglings. These visits enabled us to monitor the recruitment of marked birds. Because juveniles sometimes come back to visit their natal area without actually breeding (Ferrer 1993), a bird was considered recruited when it was observed, on several occasions in the same year, to be mated and to exhibit territorial behavior such as roosting in the breeding area, building a nest, and courting.

Prefledging factors affecting the probability of recruitment.First, using the data set from marked nestlings, we tested univariately whether the recruitment probability was related to the nestling's sex, population of origin, cohort identity, rank, body condition at fledging, foot length (corrected by sex), hatching date, number of siblings, current breeding success (CBS), and past breeding success (PBS). Body condition was estimated from residuals of an analysis of variance (ANOVA) with weight as the dependent variable, age as a covariate, and sex and population as fixed factors. Measurements of breeding success were standardized for year and study area. "CBS" refers to the birth year of the nestling, whereas "PBS" refers to the previous 3 years and thus accounts 
for the effects of both parental and territorial quality. Second, we used multivariate analyses with recruitment as the dependent variable (either yes or no) and territory of origin and cohort identity as random factors. The explanatory variables were sex, body condition, CBS, and PBS. Aside from their interest from a biological or conservation point of view, these variables accounted for most of the variation in the other variables that were first analyzed univariately.

Age of recruitment.-We applied a recently developed approach based on estimating both resighting and seniority probabilities (Pradel 1996, Pradel et al. 1997, Oro and Pradel 2000). The main advantage of this approach is that it makes no assumptions regarding adult survival. Two types of parameters are estimated: seniority $(\gamma)$ and resighting probabilities $(p)$. The seniority probability is defined as the probability that a bird that is territorial in a given year has been territorial previously-that is, it is an experienced bird (Pradel 1996). The proportion of first-time breeders $(\beta)$ is $1-\gamma$ and can be calculated for every cohort. In the seniority analysis, recapture histories are reversed and then examined by means of a classical survival analysis. Therefore, most of the assumptions made in this approach are analogous to those made when studying survival with capture-recapture data.

Seniority analyses were based on the subset of data from the French population (1990-2007). Once the full time- and agedependent model was accepted and retained as the initial model, we generated a set of models with different numbers of age-classes (1-6). The youngest age-class corresponded to 2-year-old birds. Categorical, linear, logarithmic, and the quadratic effects of age on seniority on a logit scale were considered (only the most relevant models are shown below), as were models accounting for the effects of sex.

Natal dispersal distance.-In univariate analyses, the factors considered to affect dispersal distance were the nestling's sex, population of origin, rank, and body condition at banding, the number of fledglings and the CBS of the natal territory, and the PBS of the recruitment territory. Secondly, we applied multivariate analyses with distance as the dependent variable. The explanatory variables used were sex, area of origin, body condition, the CBS of the natal territory, and the PBS of the recruitment territory.

Natal dispersal direction.-To study whether natal dispersal direction differed from an expected random dispersion between available sites, we performed randomization tests of goodness-offit for circular data (5,000 randomizations). All dispersal angles were recoded into eight $45^{\circ}$ arcs, and for each area two possible scenarios were considered: (1) birds can disperse only to territories within their population of origin, or (2) birds can disperse to territories anywhere within the species' French-Iberian range. To generate the expected distribution of directions, we randomly assigned dispersing birds to a territory of recruitment (1,000 replicates) and recorded, for each individual, the angle between the horizontal axis and the line between the origin (which is fixed) and recruitment territories.

Territorial attractiveness.-Using the data sets from the monitored territories, we analyzed whether the territorial features were related to the probability that a territory was used by an inexperienced bird. Territories were considered to be used by an inexperienced individual in a given year when we observed (1) reoccupation of an unoccupied territory or (2) a replacement within an occupied territory. Territories were considered not used by a new individual when (1) the disappearance of a territorial bird was not followed by a replacement or (2) an unoccupied territory was not reoccupied. Using multivariate analyses, we tested whether the recruitment of a new bird (either yes or no) was related to previous occupancy status, the turnover rate (the ratio of the number of years a territorial individual was replaced by another bird or disappeared to the number of years the territory was occupied), conspecific density (number of neighboring occupied territories in radii of 10,30 , and $50 \mathrm{~km}$ ), global breeding success (mean breeding success standardized by year and area, considering all years in which the territory was occupied), and the PBS of the territory. Territorial identity and year of recruitment were used as random factors. We made several assumptions in our analyses. (1) Occupied territories in which territorial birds survived or did not disperse between consecutive years were not available for occupation by new individuals and, thus, were not considered in the analyses. Hence, our measurement of attractiveness is applicable only to available territories, because some high-quality territories may appear to be highly attractive to recruiting birds but are unavailable because they remain occupied. (2) Unoccupied territories were considered suitable for occupation in the 5 years after being abandoned or before their reoccupation (76.9\% of reoccupation events occurred within 5 years of abandonment; $n=13$ ). (3) New birds had no previous territorial experience. Available data suggest that breeding dispersal is rare in Bonelli's Eagles (see below).

Statistical methods.-In seniority analyses, model selection was made on the basis of Akaike's information criterion corrected for small sample size ( $\mathrm{AIC}_{\mathrm{c}}$ ), the model with the smallest $\mathrm{AIC}_{\mathrm{c}}$ value being selected (Burnham and Anderson 2002). In univariate tests, parametric tests were applied when test assumptions were not violated; otherwise we used nonparametric tests. In multivariate tests, we applied generalized linear mixed models (GLMMs; McCullagh and Nelder 1983). This allowed us to account for the potential non-independence of clustered observations. Dependent variables were modeled either as a binomial (probabilities) or normal response variable (log-transformed dispersal distance), using logit and identity link functions, respectively. Error distributions were assumed to be either binomially or normally distributed. Each explanatory variable and its interactions were fitted to the observed data by following a forward stepwise procedure. Model comparison was done through deviance analyses and their corresponding log likelihood ratio (LR) statistic.

All $P$ values refer to two-tailed tests with a significance level of 0.05. Descriptive statistics on measured variables are reported as means \pm SD. Parameter estimates from statistical models are reported as parameter \pm SE unless otherwise stated. We conducted statistical analyses using SPSS, version 15.0 (SPSS, Chicago, Illinois), R software for statistical computing for GLMMs (R Development Core Team 2007), and M-SURGE, version 1.8.1, for seniority analyses (Choquet et al. 2005). Circular plots were drawn using the plotrix package for R (Lemon and Bolker 2009).

\section{Results}

A total of 45 of 451 marked nestlings recruited as territorial birds (global return rate of $9.97 \%$; Table 1). The sex ratio of recruits was seemingly male-biased in Catalonia, although we found no 
TABLE 1. Summary data on Bonelli's Eagles marked as fledglings and recruited as territorial birds from the study populations. Reported data include centrality measures (mean or ratio either for continuous or binomial variables), dispersion measures (95\% Cl for binomial variables, SD and range for continuous variables), and sample size $(n)$.

\begin{tabular}{lcc}
\hline & Catalonia & France \\
\hline Return rate (\%) & 9.02 & 10.33 \\
& $(4.74-15.67)$ & $(7.15-14.27)$ \\
Recruitment age (years) & $n=122$ & $n=329$ \\
& $3.7 \pm 1.34$ & $3.8 \pm 2.08$ \\
& $(2-7)$ & $(1-10)$ \\
Natal dispersal distance $(\mathrm{km})$ & $n=11$ & $n=34$ \\
& $(22-430)$ & $92.4 \pm 78.6$ \\
Natal dispersal direction & $n=7$ & $n=34$ \\
& $237.2^{\circ}$ & $175.4^{\circ}$ \\
& $\left(201-269^{\circ}\right)$ & $\left(12-359^{\circ}\right)$ \\
Percentage of female birds & $n=7$ & $n=34$ \\
(recruited vs. marked) & 27.27 vs. 51.63 & 55.88 vs. 46.44 \\
\hline
\end{tabular}

significant differences in the sex distribution of marked and recruited birds (France: $\chi^{2}=0.65$, df $=1, P=0.42, n=295$; Catalonia: $\chi^{2}=2.87, \mathrm{df}=1, P=0.090, n=122$ ). Eight males from the Catalan population recruited back into their population of origin, whereas 3 females recruited far from Catalonia but within the Iberian Peninsula. A female and a male were recruited in Catalonia from France (Fig. 1). The identity of 5 Catalan individuals could not be established exactly, although their plastic tags allowed us to determine their year of birth and, in one case, to establish their territory of origin.

Prefledging factors affecting the probability of recruitment.Univariate tests showed a significant effect of cohort identity on the probability of recruitment (randomized chi-square test, $\chi^{2}=40.89$, $P=0.007$ ) but no significant effect of any other variable we considered (sex: $\chi^{2}=0.03, \mathrm{df}=1, P=0.85, n=417$; population: $\chi^{2}=0.17$, $\mathrm{df}=1, P=0.68, n=451$; rank: $\chi^{2}=0.62, \mathrm{df}=1, P=0.43, n=397$; body condition: $F=0.56, \mathrm{df}=1$ and $291, P=0.45, n=296$; foot length: $F=0.12, \mathrm{df}=1$ and $42, P=0.73, n=45$; hatching date: $t=-1.07, \mathrm{df}=$ 20.226, $P=0.29, n=310$; number of fledglings: $\chi^{2}=0.51, \mathrm{df}=1$, $P=0.48, n=447$; CBS: $t=-1.86, \mathrm{df}=449, P=0.064, n=451$; PBS: $t=1.35, \mathrm{df}=412, P=0.18, n=414)$. Accordingly, the GLMMs revealed that cohort identity had the most important effect on the probability of recruitment (LR test: $\chi^{2}=6.91, \mathrm{df}=21, P=0.008$ ); the analysis of the coefficients for this random factor revealed high values for the years 1996 and 2002 (variance $=0.462$; Fig. 2A). Also, CBS in the territory of origin showed a marginally significant effect (coefficient $=0.572 \pm 0.320$; bootstrapped LR test: $P=$ 0.057; 95\% confidence interval [CI]: 0.042-0.071), in that fledglings from the most successful territories had higher probabilities of being recruited (Fig. 2B). The Hosmer-Lemeshow statistic showed an acceptable fit for the model $\left(\chi^{2}=5.63, \mathrm{df}=28, P=0.68\right)$, although the model explained only $3.5 \%$ of the original deviance (final model: deviance $=260.5, n=451$ ). Finally, we found that the effect of territory modeled as a random factor did not improve the fit of the model (LR test: $\chi^{2}=2.03, \mathrm{df}=21, P=0.15$ ), although this result may be attributable to the small sample size available in

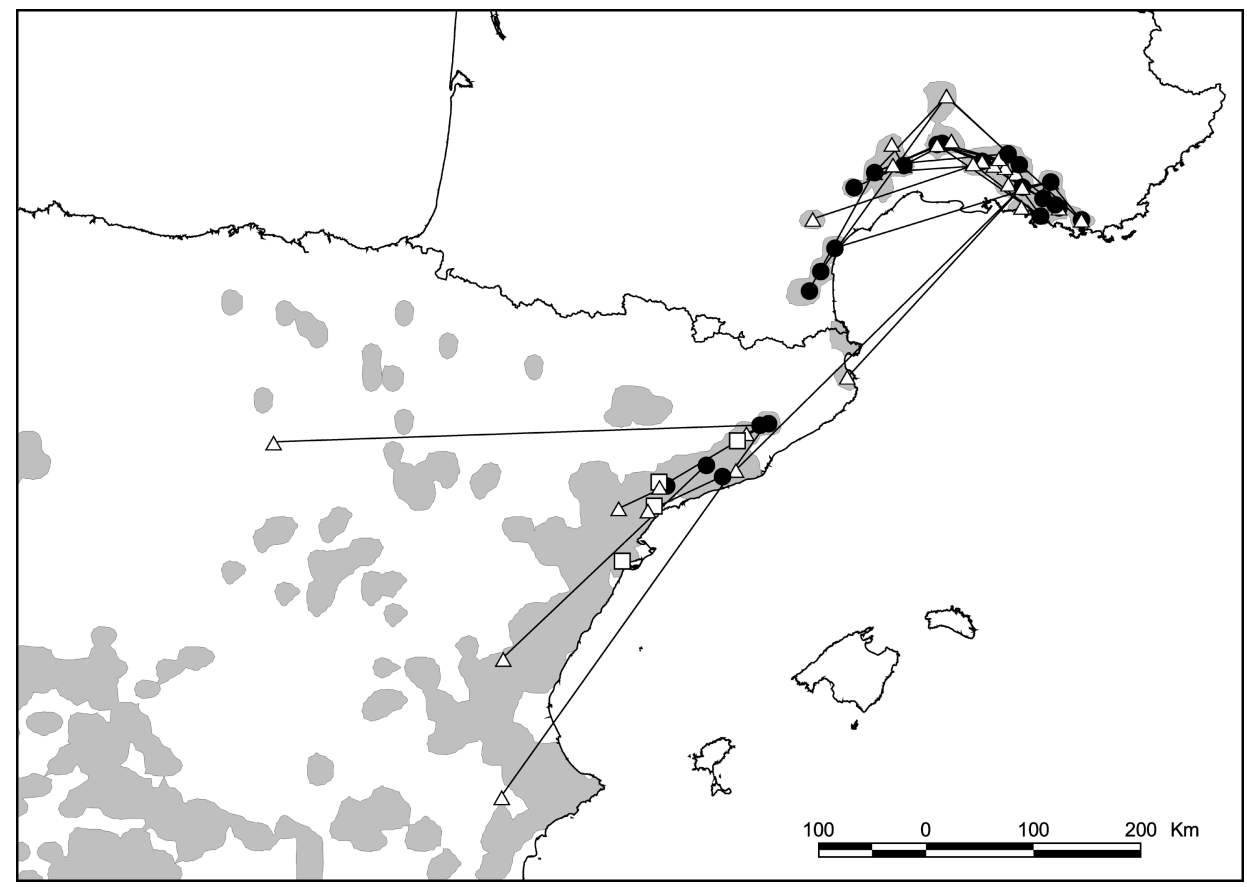

FIG. 1. Recruitment of Bonelli's Eagles in southeastern France and Catalonia (northeastern Spain). Lines join natal sites (solid circles) and recruitment sites (empty triangles). Recruitment of marked birds of unknown origin is also shown (empty squares). The current distribution range of Bonelli's Eagle around the studied populations is represented by the shaded area. 

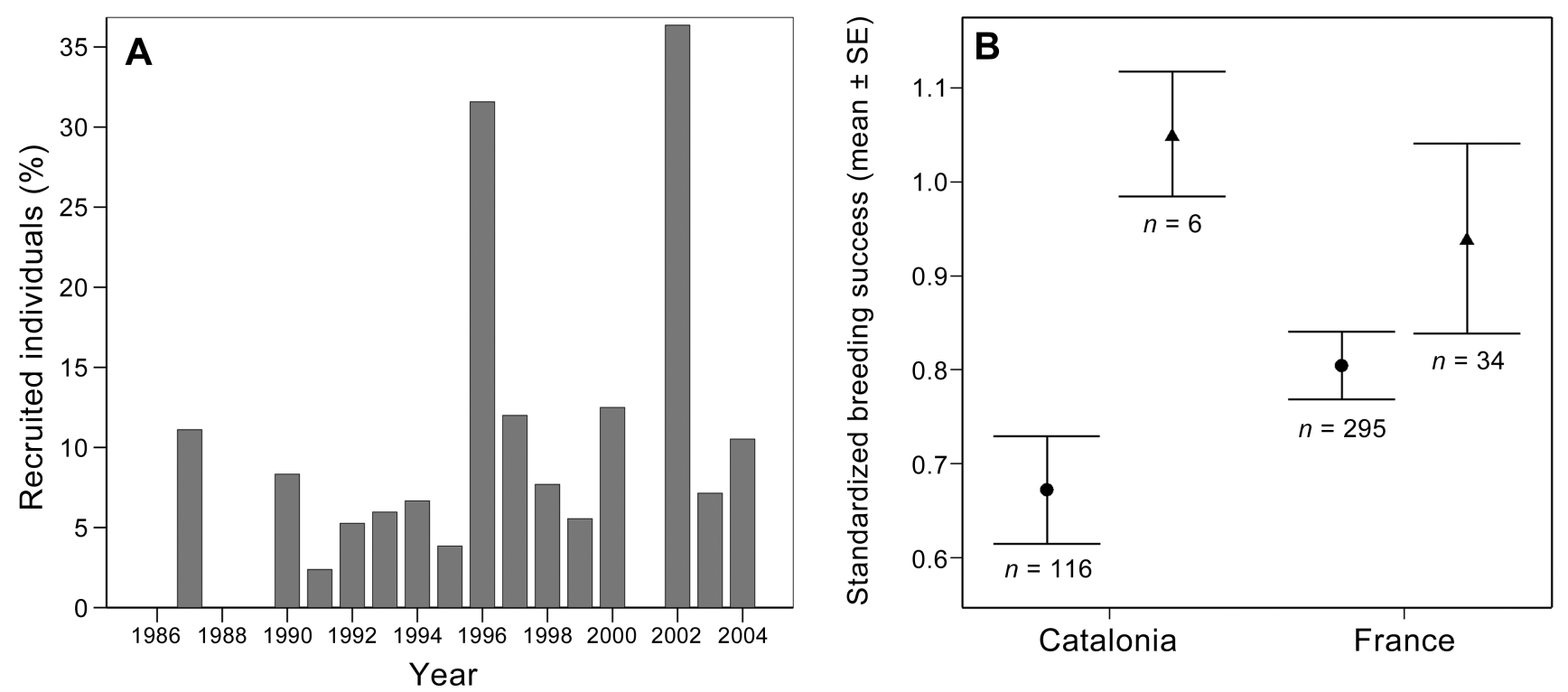

FIG. 2. Determinants of the probability of recruitment of Bonelli's Eagles in southeastern France and Catalonia. (A) Percentage of nestlings that were subsequently recruited as territorial birds, depending on the birth year (i.e., cohort). (B) Breeding success (corrected by year and area) of territories where fledglings either subsequently recruited as a territorial bird (solid triangles) or did not (solid circles). For each category, we show mean values and their associated standard errors.

many territories. Indeed, our data revealed that 24 of 40 recruits originated from just 7 territories $(n=52$ territories) that correspond to $\sim 21$ parents.

Age of recruitment.-The mean observed age of recruitment was $3.8 \pm 1.92$ years (median and mode $=3 ; n=45$ ), and values were consistent within sexes and populations (France: females: $4.0 \pm 1.74$, range: $2-10, n=19$; males: $3.5 \pm 2.50$, range: $1-10, n=$ 15; Catalonia: females: $3.3 \pm 0.57$, range: $3-4, n=3$; males: $3.9 \pm$ 1.55 , range: $2-7, n=8$ ). For the seniority analyses, we obtained the capture-resighting histories of 34 individuals from 15 cohorts (1990-2004). The full time- and age-dependent model $\left(\gamma_{\mathrm{a}^{\prime \prime} \mathrm{t}}\right.$, $\left.\mathrm{p}_{\mathrm{a}^{*} \mathrm{t}}\right)$ was accepted $\left(\chi^{2}=2.79, \mathrm{df}=6, P=0.83\right)$. In the set of evaluated models, the best and second-best models considered three age-classes, and the third considered four age-classes (Table 2). All the best models considered that the resighting probability was constant over time (estimates ranging from $59.6 \%$ to $62.1 \%$; 95\% CI: 46.16-74.66\%). The first and second models yielded very similar parameter estimates. The probability of being inexperienced $(\beta)$ was estimated at $99.9 \%$ and $99.5 \%$ for 2 -year-old and $80.4 \%$ and $80.8 \%$ for 3 -year-old territorial birds, respectively, but fell to $\sim 8 \%$ for 4 -year-old or older territorial birds (Fig. 3A). The selected model using four age-classes estimated that the probability of being a first-time breeder was $98.5 \%$ for a 2 -year-old territorial bird, $76.3 \%$ for a 3 -year-old, $27.2 \%$ for a 4 -year-old, and $6.6 \%$ for a 5 -year-old or older territorial bird (Fig. 3B). The main differences in the models using four age-classes (as opposed to those with three age-classes) are found in the older age-classes, although all selected models provided relatively high values for the probability of being inexperienced in the oldest age-class (95\% CI: 2.3-20.2\%). Finally, the effect of sex was found in two models to be $<2.08 \mathrm{AIC}_{\mathrm{c}}$ points from the best model (Table 2). However, the effect of sex on the estimates was very weak, and it is difficult to draw any significant conclusions regarding tendencies.

Distance of natal dispersal.-The mean natal dispersal distance for recruited birds was $107.1 \pm 103.5 \mathrm{~km}(n=41)$ and ranged from $19.4 \mathrm{~km}$ in a French male to $430 \mathrm{~km}$ in a Catalan female.

TABLE 2. Model selection for seniority probability $(\gamma)$ and resighting probability $(p)$. Selected models are in bold. For each model, we give model description, deviance, number of estimable parameters $\left(n_{\mathrm{p}}\right)$, and the Akaike's information criterion corrected for small sample size (AIC $C_{c}$. Model notation indicates seniority probabilities $(\gamma)$, resighting probabilities $(p)$, age effect (a), linear effect of age effect in a logit scale (A), logarithmic effect of age in a logit scale (In A), time effect (t), and a constant effect (i). The number of age-classes considered is reported in parentheses.

\begin{tabular}{|c|c|c|c|}
\hline Model description & Deviance & $n_{\mathrm{p}}$ & $\mathrm{AIC}_{\mathrm{c}}$ \\
\hline$\gamma_{\ln \mathrm{A}(3)}, \mathbf{p}_{\mathrm{i}}$ & 136.29 & 3 & 142.73 \\
\hline$\gamma_{\mathrm{A}(3)}, \mathbf{p}_{\mathrm{i}}$ & 136.34 & 3 & 142.78 \\
\hline$\gamma_{\ln \mathrm{A}(4)}, \mathbf{p}_{\mathrm{i}}$ & 137.50 & 3 & 143.94 \\
\hline$\gamma_{\ln A(3)^{*} \operatorname{sex}^{\prime}} p_{i}$ & 136.05 & 4 & 144.79 \\
\hline$\gamma_{\mathrm{A}(3)^{*} \mathrm{sex}^{\prime}} \mathrm{p}_{\mathrm{i}}$ & 136.06 & 4 & 144.80 \\
\hline$\gamma_{\mathrm{A}(4)}, \mathrm{p}_{\mathrm{i}}$ & 138.48 & 3 & 144.92 \\
\hline$\gamma_{a(3)}, p_{i}$ & 136.28 & 4 & 145.02 \\
\hline$\gamma_{\ln A(4))^{*} e^{\prime}}, p_{i}$ & 137.49 & 4 & 146.23 \\
\hline$\gamma_{\mathrm{a}(4)}, \mathrm{p}_{\mathrm{i}}$ & 136.26 & 5 & 147.39 \\
\hline$\gamma_{\mathrm{a}(5)}, \mathrm{p}_{\mathrm{i}}$ & 134.31 & 6 & 147.93 \\
\hline$\gamma_{\mathrm{a}(6)}, \mathrm{p}_{\mathrm{i}}$ & 133.96 & 7 & 150.16 \\
\hline$\gamma_{\mathrm{a}(2)}, \mathrm{p}_{\mathrm{i}}$ & 151.81 & 3 & 158.25 \\
\hline$\gamma_{\mathrm{sex}}, \mathrm{p}_{\mathrm{i}}$ & 177.60 & 3 & 184.04 \\
\hline$\gamma_{i}, p_{i}$ & 179.83 & 2 & 184.04 \\
\hline$\gamma_{t}, p_{t}$ & 142.81 & 28 & 252.94 \\
\hline$\gamma_{\text {sex }^{*} t^{\prime}} p_{t^{*} \operatorname{sex}}$ & 123.40 & 44 & 494.26 \\
\hline
\end{tabular}


A

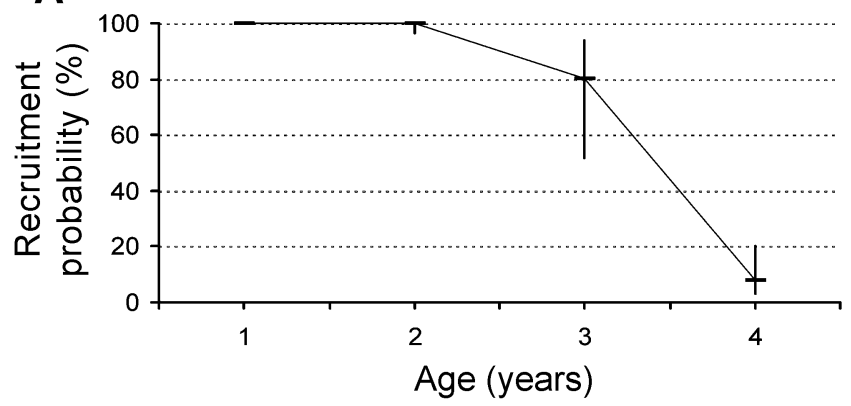

B

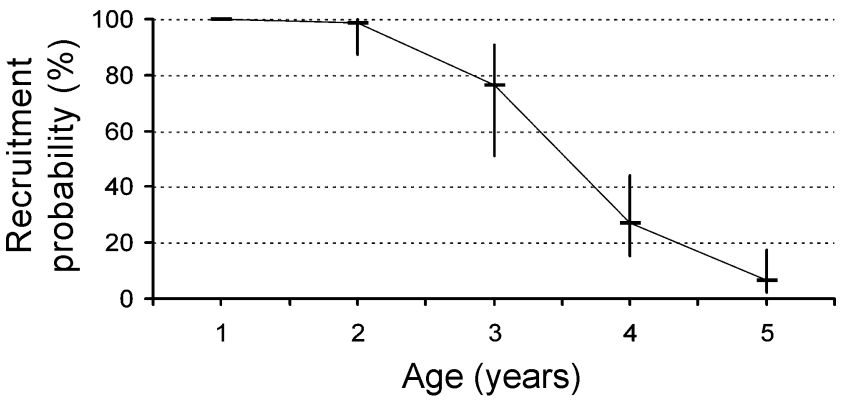

FIG. 3. Probability of recruitment of French Bonelli's Eagles by age-class under (A) a model with a logarithmic age effect, considering three age-classes and constant resighting probability $\left(\gamma_{\ln A(3)}, \mathrm{p}_{\mathrm{i}}\right)$, and $(\mathrm{B})$ a model with a logarithmic age effect, considering four age-classes and constant resighting probability $\left(\gamma_{\ln A(4)}, p_{i}\right)$. Recruitment probability is expressed as the percentage of territorial individuals without previous experience $(\beta \pm I C)$, which can be estimated from the seniority probability $(\gamma)$ as $\beta=1-\gamma$. Recruitment probability for 1 -year-olds was fixed at 100 because this age-class was not considered in the models (see text).

Univariate analyses showed that female birds dispersed farther than males $(t=-2.32, \mathrm{df}=39, P=0.025)$, although no significant effects were found for any other studied factor (area of birth: $t=$ 1.40, df $=39, P=0.17, n=41$; rank: $t=-0.71, \mathrm{df}=29, P=0.48, n=$ 31; body condition: $r=-0.17, P=0.52, n=17$; number of fledglings: $t=-1.82, \mathrm{df}=36, P=0.077, n=38$; CBS: $r=0.21, P=0.19, n=40$; PBS: $r=-0.09, P=0.58, n=40)$. Additionally, multivariate analyses showed that sex, population of origin, and the interaction between these factors had a significant effect on dispersal distance (intercept: $0.491 \pm 0.746, P=0.51$; sex: $1.246 \pm 0.491, P=0.015$; population: $0.545 \pm 0.403, P=0.18$; sex*population: $-0.538 \pm 0.263$, $P=0.047$; deviance: $4.38 ; n=41$; see Fig. 4). Females dispersed farther than males, and Catalan females $(327.3 \pm 173.5 \mathrm{~km}$, range: 127-430, $n=3$ ) dispersed farther than French females (106.8 \pm 86.8 , range: $23-395, n=19$ ). Dispersal distances of males from the

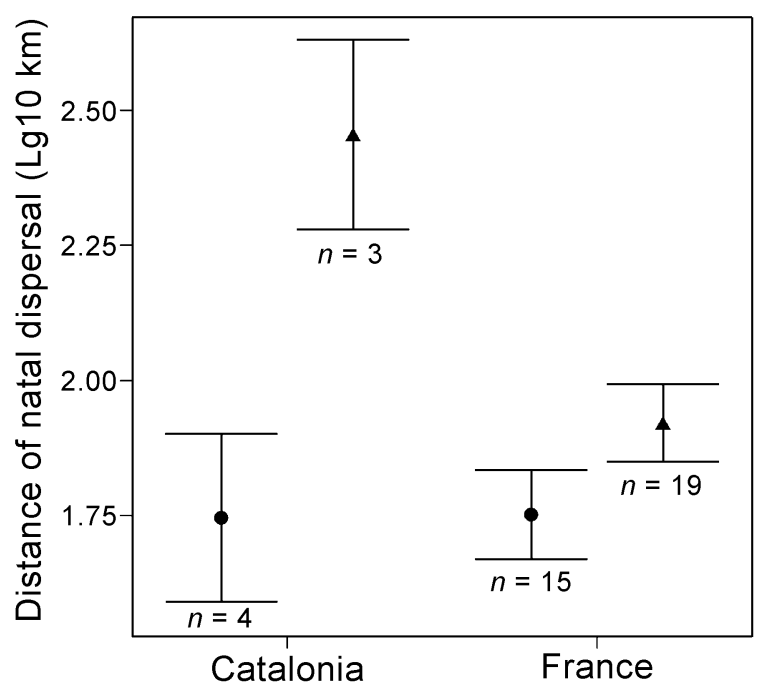

FIG. 4. Natal dispersal distance of male (solid circles) and female (solid triangles) Bonelli's Eagles from Catalonia and France. For each category, we show mean values, their associated standard error, and sample sizes $(n)$. two areas did not differ (France: $74.3 \pm 65.2$, range: $19-239, n=15$; Catalonia: $66.0 \pm 40.5$, range: $22-117, n=4$ ).

Direction of natal dispersal.-Randomization tests showed that the direction of natal dispersal did not differ significantly from the expected random pattern for birds from Catalonia for available sites within the population of origin $(P=0.82)$ and in the whole French-Iberian range $(P=1$; Fig. 5). Dispersal direction of French recruits fit well to a random dispersal between available sites in France $(P=1)$ but differed significantly from the expected pattern for random dispersal within the whole French-Iberian range $(P<0.001$; Fig. 5$)$.

Territory attractiveness.-Previously occupied territories were more likely to be used by a new individual. Coefficient magnitude and explained variance suggest that occupancy is the most important factor explaining attractiveness of territories (Table 3 and Fig. 6A), except in the case of French males. However, in a similar model that did not consider the random territorial factor, previous occupancy was the most important effect for French males. The number of neighboring territories also increased territorial attractiveness in all the analyses (Table 3). Our results suggest that the effect of conspecifics is most important within a $10-\mathrm{km}$ radius, although conspecific density within radii of 10 and $30 \mathrm{~km}$ is highly correlated in our data set (Kendall's $\tau_{\mathrm{b}} R=0.31, P<0.001, n=117$ ). Moreover, conspecific density showed a significant interaction with previous occupancy status for French females, in that the effect of conspecifics was more important in previously unoccupied territories (Fig. 6B). Finally, PBS positively influenced the likelihood of attracting a recruit, except if the recruit was a French male (Table 3). The interaction between PBS and occupancy was also retained in the final model for both French and Catalan females; occupied territories with higher PBS values were more likely to be used (Fig. 6C). For French females, the coefficient of the PBS effect was negative. However, when considering the sign and magnitude of occupancy and the interaction between occupancy and PBS effects, the model indicates that attractiveness in occupied territories is greater for territories with higher PBS values. There was an apparent decline in the PBS effect on Catalan males, for territories with a high number of neighbors (Fig. 6D), although this interaction was not retained in the final model. 


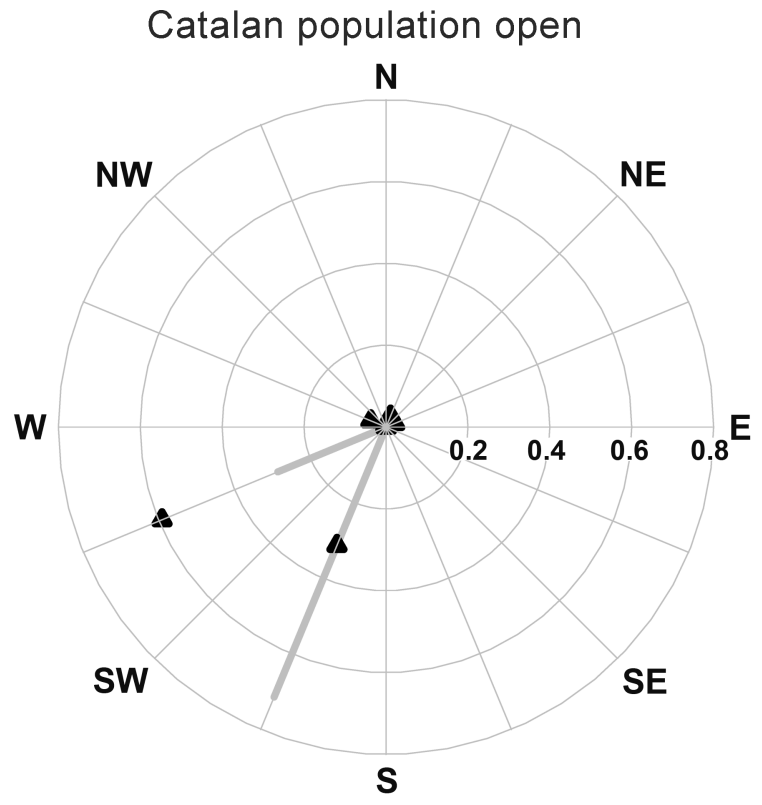

\section{Catalan population closed}

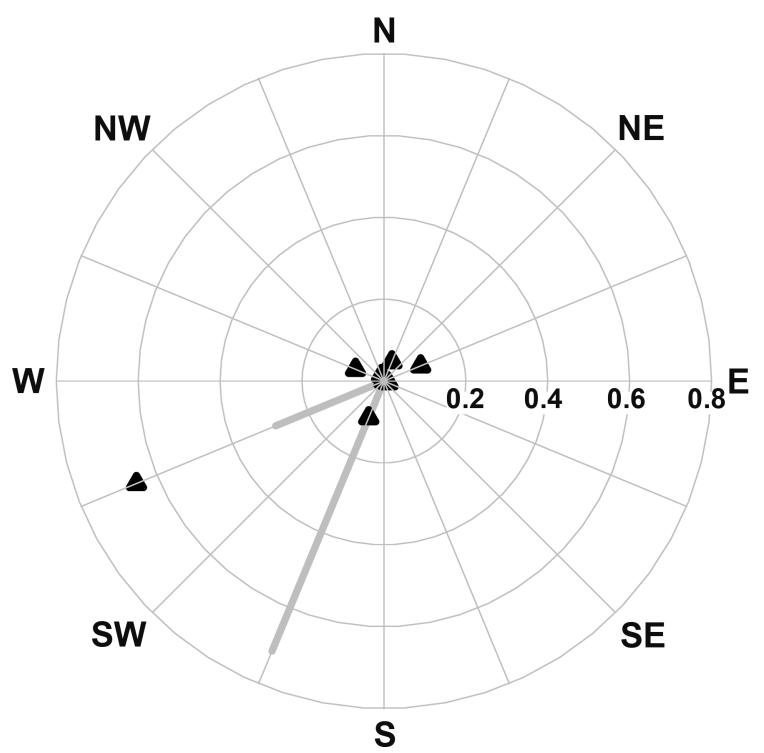

French population open

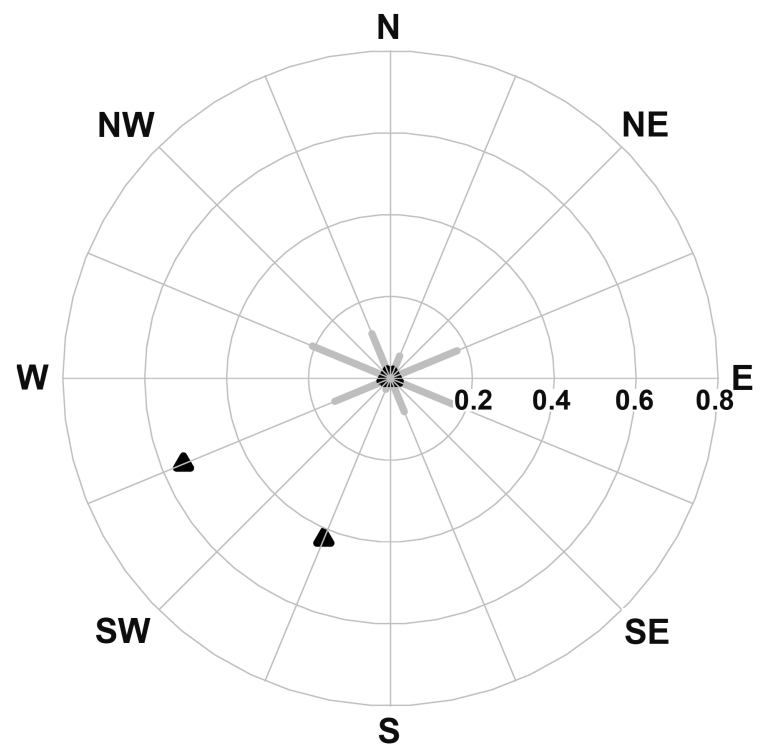

French population closed

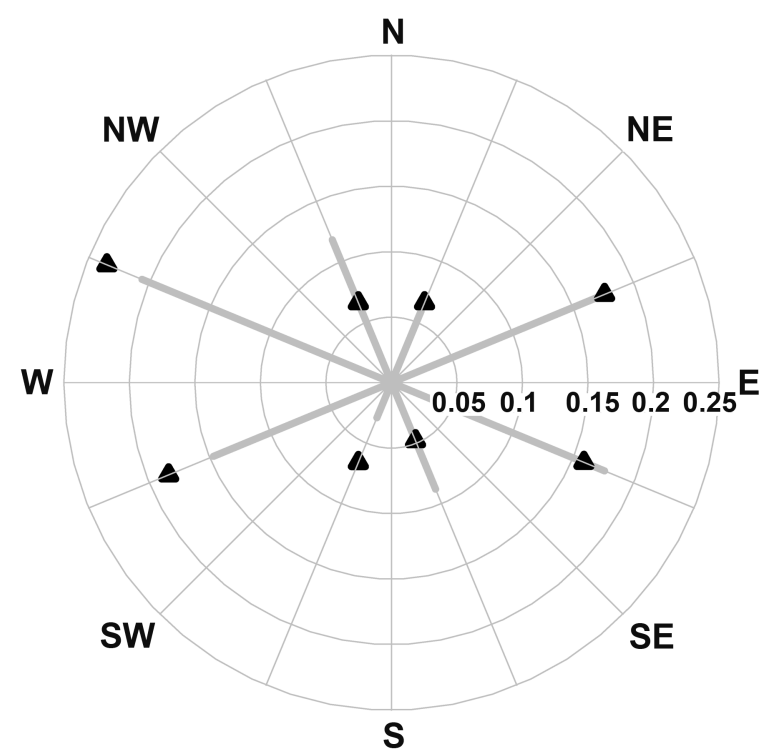

FIG. 5. Observed and expected probabilities of natal dispersal directions of individual Bonelli's Eagles from Catalonia and France. Solid gray bars indicate observed probabilities. Solid triangles indicate expected probabilities under the assumption of uniform dispersal to territories anywhere within the species' French-Iberian range (top) or to territories within their population of origin (bottom).

\section{Discussion}

The factors determining recruitment processes in birds depend on individual and parental characteristics, on the characteristics of territories and years of birth, and on territories and years of recruitment (e.g., Newton 1989, Tella et al. 2000, Müller et al. 2005, Rutz and Bijlsma 2006). However, detailed information on the determinants of this process in territorial raptors is scarce. Our results show that the determinants of recruitment in Bonelli's Eagles act in a complex fashion on several parts of this process and show temporal and spatial variation. These results highlight the importance of conducting long-term studies over extensive areas when approaching this issue in long-lived territorial bird species.

We found that the probability that a fledgling was subsequently recruited as a territorial bird was highly dependent on its year of birth. The survival probabilities of nonadult individuals may be correlated with interannual variations in environmental variables or constrained in some years by density dependence 
TABLE 3. Generalized linear mixed models for the probability that a territory was occupied by an inexperienced individual, using binomial error and logistic link. Deviance and sample size of final models are shown between brackets.

\begin{tabular}{|c|c|c|c|}
\hline Factor & Coefficient & SE & $P$ \\
\hline \multicolumn{4}{|c|}{ Males from the Catalan population $($ deviance $=136.32 ; n=149)$} \\
\hline Intercept & -2.080 & 0.590 & $<0.001$ \\
\hline Previous occupancy status & 2.181 & 0.538 & $<0.001$ \\
\hline Number of neighbors in a $10-\mathrm{km}$ radius & 0.363 & 0.143 & 0.011 \\
\hline Past breeding success (PBS) & 0.975 & 0.398 & 0.014 \\
\hline \multicolumn{4}{|c|}{ Males from the French population $($ deviance $=70.48 ; n=111)$} \\
\hline Intercept & -6.078 & 7.073 & 0.390 \\
\hline Number of neighbors in a $10-\mathrm{km}$ radius & 13.224 & 5.291 & 0.012 \\
\hline Territory (random factor) & $\begin{array}{l}323.590 \\
\text { (variance) }\end{array}$ & $\begin{array}{c}17.989 \\
(\mathrm{SD})\end{array}$ & \\
\hline \multicolumn{4}{|c|}{ Females from the Catalan population $($ deviance $=118.27 ; n=133)$} \\
\hline Intercept & -3.906 & 1.381 & 0.004 \\
\hline Previous occupancy status & 3.744 & 1.425 & 0.008 \\
\hline PBS & 1.300 & 0.528 & 0.013 \\
\hline Number of neighbors in a $10-\mathrm{km}$ radius & 1.302 & 0.428 & 0.002 \\
\hline Previous occupancy * PBS & -0.934 & 0.468 & 0.045 \\
\hline Territory (random factor) & $\begin{array}{c}2.115 \\
\text { (variance) }\end{array}$ & $\begin{array}{l}1.454 \\
\text { (SD) }\end{array}$ & \\
\hline \multicolumn{4}{|c|}{ Females from the French population $($ deviance $=87.36 ; n=113$ ) } \\
\hline Intercept & -11.076 & 3.777 & 0.003 \\
\hline Previous occupancy status & 13.168 & 3.907 & $<0.001$ \\
\hline Number of neighbors in a $30-\mathrm{km}$ radius & 0.767 & 0.268 & 0.004 \\
\hline PBS & -8.094 & 4.362 & 0.063 \\
\hline Previous occupancy * number of neighbors & -0.992 & 0.337 & 0.003 \\
\hline Previous occupancy * PBS & 9.471 & 4.411 & 0.031 \\
\hline
\end{tabular}

(Krüger 2007, Tavecchia et al. 2007). Our results did not allow us to establish any clear relationship between recruitment probability and nestling characteristics such as body size or condition (but see Korpimäki and Wiehn 1998, Sedinger and Chelgren 2007). However, nestlings from territories with better breeding success seemed more likely to be recruited. Parental quality is an important determinant of recruitment probability in birds (Saino et al. 1997, Tella et al. 2000), and current performance may be correlated with both parental and territorial quality (Newton 1998, Carrete et al. 2006), although we could not effectively separate these two effects, which may be interrelated (Ferrer and Bisson 2003).

As expected, the tendency to breed increased with age (e.g., Pradel et al. 1997). Our seniority analyses showed that most Bonelli's Eagles recruit in either the third or fourth year of life and that recruitment before the second year is very rare. It is known that in most long-lived birds the recruitment age is not a fixed value and may act as a compensatory demographic mechanism (Ferrer et al. 2003, 2004). It is thought that in our study populations, which underwent intense adult mortality during the study period (Real and Mañosa 1997, A. Hernández-Matías et al. unpubl. data), the shape of the recruitment curve moved toward younger ageclasses. However, seniority analyses also indicate a relatively high proportion of recruits among 5 -year-olds and in older age-classes $(6.5-8 \%)$ that is difficult to interpret given the large confidence intervals of the probability of recruitment that were estimated for very old individuals. Apparently, late-recruiting individuals may have bred unnoticed for several years at the same site at which they were eventually detected, given that our estimate of the yearly probability of not recording a marked bird was relatively high (95\% CI: 0.53-0.25). Alternatively, recruits could have bred elsewhere before they were observed being territorial, although available data suggest that breeding dispersal is rare in Bonelli's Eagles (but see Ferrer and Bisson 2003). Only 1 of 35 banded breeding birds in France dispersed during the 1992-2007 period (present study), whereas none of the 25 radiotracked birds in Catalonia did so during a 5-year monitoring program (J. Real unpubl. data). An alternative explanation is that part of the Bonelli's Eagle population recruits at older ages, which would indicate the existence of a floating population of nonterritorial adult individuals (Newton 1992, Kenward et al. 2000). Nevertheless, available data from both breeding and dispersal areas showed that there was only a low presence of nonresident and dispersing adult birds (Mañosa et al. 1998, J. Real unpubl. data).

Natal dispersal distance appeared to be highly related to sex, in that female Bonelli's Eagles recruited at larger distances than males (Newton 1979, Greenwood and Harvey 1982, Forero et al. 1999, Serrano et al. 2003; but see Negro et al. 1997). Additionally, we found a significant interaction between sex and population of origin for natal dispersal distances: females from Catalonia dispersed farther than females from France. Local 

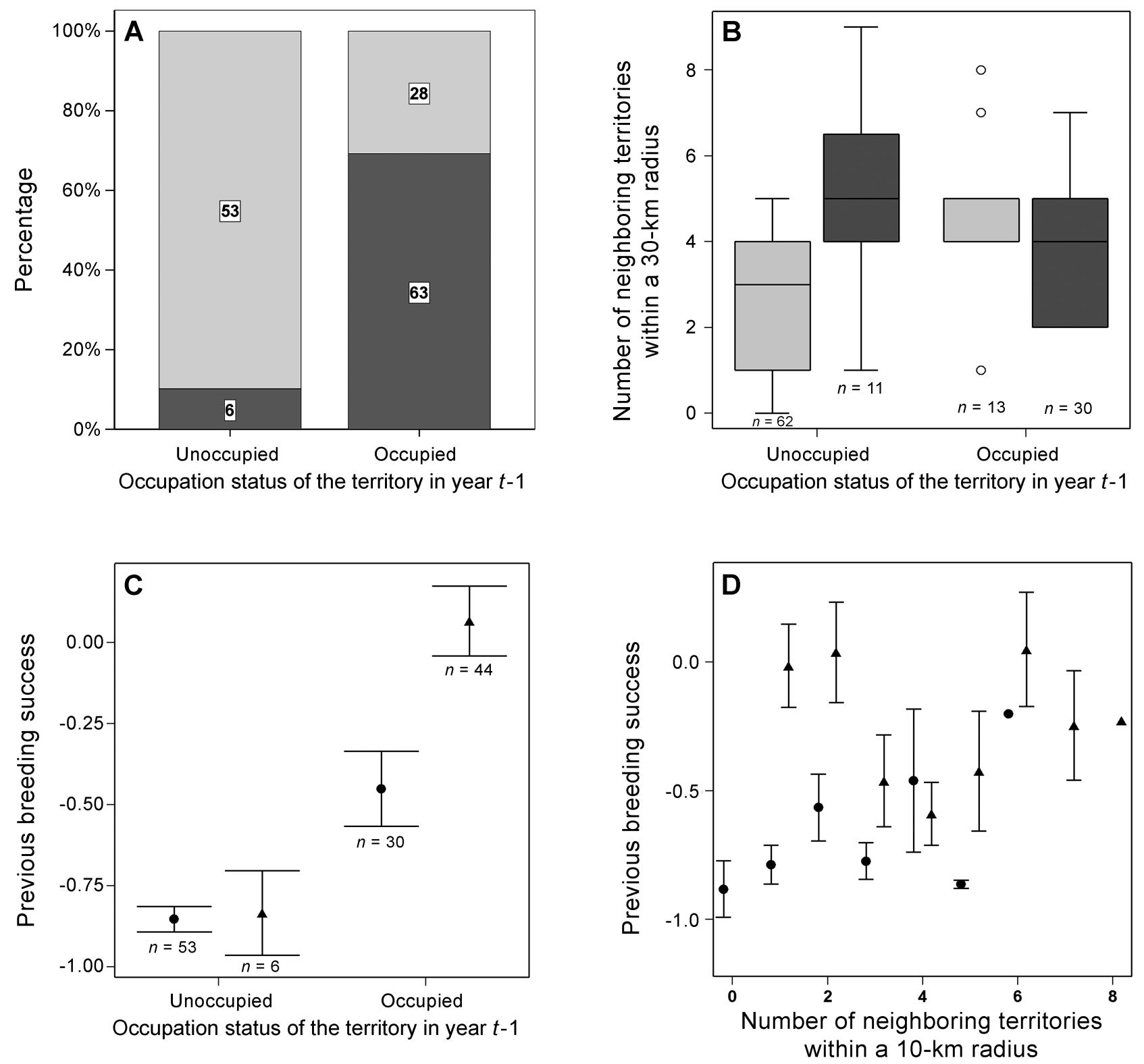

FIG. 6. Determinants of territory attractiveness to inexperienced Bonelli's Eagles in southeastern France and Catalonia. (A) Percentage of territories used by naive males (dark gray), depending on the occupancy status of the territory in Catalonia. Observed frequencies are given within the bars. (B) Number of neighboring territories in a 30-km radius for territories either used (dark boxes) or not used (light boxes) by a naive female, depending on its occupancy status in the French population. Sample size ( $n$ ) and atypical values (empty circles) are also shown. (C and D) Past breeding success (PBS) in relation to $(C)$ the recruitment of inexperienced females and the previous occupancy status of the territory and (D) the recruitment of inexperienced males and the number of neighboring territories in a 10-km radius in Catalonia. For each category, we show mean values for used (solid triangles) and unused (solid circles) territories, their associated standard errors, and sample size ( $n$ ).

territorial density in Catalonia was about twice that recorded in France, so observed differences may have been influenced by local intraspecific competition (reviewed in Matthysen 2005). An alternative explanation is that the lack of suitable breeding areas around French breeding sites forced a higher percentage of French females to remain within their population of origin. Both observed distances and directions of natal dispersal suggest that the Catalan population has higher levels of individual exchange with the rest of the Iberian population than the French population (Real and Mañosa 1997, 2001). However, genetic analyses have revealed no evidence of genetic structuring within several occidental Bonelli's Eagle populations (Cardia et al. 2000, Cadahía et al. 2007a), so population exchanges may well occur (but see Mira 2006). 
Finally, the attractiveness to recruiting birds of available territories was favored by previous occupation, higher numbers of neighbors, and higher PBS in the territory. First, occupation may indicate that a territory is suitable for reproduction (Sergio and Newton 2003), whereas an unoccupied, apparently suitable territory may indicate that factors exist that either negatively affect survival rates or favor dispersal. Second, recruitment decisions based on conspecific density have been previously described for both colonial (Oro and Pradel 2000, Serrano et al. 2003) and territorial birds (Muller et al. 1997, Lahaye et al. 2001). Occupation of new territories was reported to occur in areas adjacent to previously used territories in territorial raptors (Margalida et al. 2008). In our study, the observed correlation between local density and attractiveness may have resulted from the presence of conspecifics, resource availability (e.g., cliffs), or a combination of both factors (Muller et al. 1997). Third, our results are compatible with the "habitat-copying hypothesis" (Danchin et al. 2004, Hénaux et al. 2007), which predicts that individuals use information from behavior of conspecifics that indicates habitat quality (i.e., PBS). However, our estimated PBS is probably correlated with several territorial characteristics, such as prey availability and partner quality. Thus, recruitment decisions may be based on one or several of these biotic variables.

Our results show that for long-lived territorial birds, the determinants of recruitment act in a complex way at several spatial and temporal scales. Aside from individual characteristics, parentrelated features and environmental scenarios during the prebreeding period of birds' lives shape recruitment processes (e.g., Müller et al. 2005). Additionally, we provide, for the first time, detailed information regarding the processes of natal dispersal and territorial recruitment in Bonelli's Eagles. At a conservation level, this contribution offers good estimates of recruitment probabilities of different age-classes in this species, which will allow us to employ suitable demographic models for analyzing the viability of Bonelli's Eagle populations. Additionally, our study highlights that a small number of territories (i.e., individuals) contribute a large proportion of recruited birds (Newton 1989, Ferrer and Donazar 1996) and that the areas of highest population densities were more attractive for recruiting Bonelli's Eagles. These results suggest that high-quality territories play a key role in maintaining numbers of Bonelli's Eagles and that a minimum threshold of territorial density appears to be necessary to reduce the probability that territories are not abandoned. Hence, in addition to improving preadult and adult survival (Real and Mañosa 1997, Soutullo et al. 2008), conservation work should aim both to protect key occupied territories and restore former territories, particularly in low-density areas. Finally, our results reveal that natal dispersal movements connect several local Bonelli's Eagle populations, including the isolated French nuclei, and that conservation actions must thus be undertaken at an international level.

\section{ACKNOWLEDGMENTS}

Comments from T. Katzner, S. G. Sealy, M. J. Bechard, and an anonymous referee greatly improved previous versions of the manuscript. M. Lockwood revised the English. R. Bosch, À. Rollan, A. Tintó, and J. Lemon helped edit the figures. A. Sanz, G. Tavecchia, E. Sebastián, and D. Oro provided helpful comments for GLM analyses. In Catalonia, S. Mañosa, A. Tintó, R. del Amo, J. Codina, R. Bosch,
F. Parés, and many other observers provided invaluable help during field work, and C. Castell greatly contributed to the achievement of this study. Nestlings were banded under permission of Servei de Fauna (Generalitat de Catalunya). In France, G.C. and J.-M. Cugnasse (Office National de la Chasse et de la Faune Sauvage) initiated the ringing scheme, N. Pierre (Conservatoire-Études des Écosystèmes de Provence) coordinated the Provence-Alpes-Côte d'Azur region, M. Mure (Centre Ornithologique Rhône-Alpes) monitored the Ardeche region, Conservatoire des Espaces Naturels du Languedoc-Roussillon coordinated the national plan for restoration and coordinated monitoring in Languedoc-Roussillon, and many observers allowed the collection of data. This study was supported by the Spanish Ministerio de Educación y Ciencia through project CGL2007-64805/BOS and grant SAB-2006-0014/Roger Pradel, Fundació Miquel Torres (Bodegas Miquel Torres), and Oficina Tècnica de Planificació i Anàlisi Territorial (Diputació de Barcelona).

\section{Literature Cited}

Arroyo, B., E. Ferreiro, and V. Garza. 1998. Causas de la regresión del Águila Perdicera Hieraaetus fasciatus en España Central. Pages 291-304 in Holartic Birds of Prey (R. D. Chancellor, B.-U. Meyburg, and J. J. Ferrero, Eds.). ADENEX-WWGBP, Merida, Spain.

BeCKer, P. H., AND J. S. BRAdLEy. 2007. The role of intrinsic factors for the recruitment process in long-lived birds. Journal of Ornithology 148 (Supplement 2):S377-S384.

BirdLife International. 2004. Birds in Europe: Population estimates, trends and conservation status. BirdLife Consevation Series, no. 12. BirdLife International, Cambridge, United Kingdom.

Burnham, K. P., And D. R. Anderson. 2002. Model Selection and Multimodel Inference: A Practical Information-Theoretic Approach, 2nd ed. Springer-Verlag, New York.

CAdAhía, L., J. J. Negro, AND V. URios. 2007a. Low mitochondrial DNA diversity in the endangered Bonelli's Eagle (Hieraaetus fasciatus) from SW Europe (Iberia) and NW Africa. Journal of Ornithology 148:99-104.

Cadahía, L., V. Urios, and J. J. Negro. 2007b. Bonelli's Eagle Hieraaetus fasciatus juvenile dispersal: Hourly and daily movements tracked by GPS. Bird Study 54:271-274.

Cardia, P., B. Fráguas, M. Pais, T. Guillemaud, L. Palma, M. L. Cancela, N. Ferrand, and M. Wink. 2000. Preliminary genetic analysis of some western Palaearctic populations of Bonelli's Eagle, Hieraatus fasciatus. In Raptors at Risk (R. D. Chancellor and B.-U. Meyburg, Eds.). Hancock House, Blaine, Washington, and WWGBP, Berlin.

Carrete, M., J. A. Sánchez-Zapata, J. L. Tella, J. M. Gil-SánCHEZ, AND M. Moleón. 2006. Components of breeding performance in two competing species: Habitat heterogeneity, individual quality and density-dependence. Oikos 112:680-690.

Cheylan, G., A. Ravayrol, J.-M. Cugnasse, J.-M. Billet, and C. Joulot. 1996. Dispersion des aigles de Bonelli Hieraaetus fasciatus juvéniles bagués en France. Alauda 64:413-419.

Choquet, R., A. M. Reboulet, R. Pradel, O. Gimenez, and J. D. Lebreton. 2005. M-SURGE 1.8 User's Manual. CEFE, Montpellier, France.

Danchin, É., L.-A. Giraldeau, T. J. VAlone, And R. H. Wagner. 2004. Public information: From nosy neighbors to cultural evolution. Science 305:487-491. 
Del Hoyo, J., A. Elliott, and J. Sargatal, Eds. 1992. Handbook of the Birds of the World, vol. 2: New World Vultures to Guineafowl. Lynx Edicions, Barcelona, Spain.

FERrer, M. 1993. Juvenile dispersal behaviour and natal philopatry of a long-lived raptor, the Spanish Imperial Eagle Aquila adalberti. Ibis 135:132-138.

Ferrer, M., AND I. Bisson. 2003. Age and territory-quality effects on fecundity in the Spanish Imperial Eagle (Aquila adalberti). Auk 120:180-186.

Ferrer, M., And J. A. Donazar. 1996. Density-dependent fecundity by habitat heterogeneity in an increasing population of Spanish Imperial Eagles. Ecology 77:69-74.

Ferrer, M., F. Otalora, And J. M. García-Ruiz. 2004. Densitydependent age of first reproduction as a buffer affecting persistence of small populations. Ecological Applications 14:616-624.

Ferrer, M., ANd V. Penteriani. 2003. A process of pair formation leading to assortative mating: Passive age-assortative mating by habitat heterogeneity. Animal Behaviour 66:137-143.

Ferrer, M., V. Penteriani, J. Balbontín, and M. Pandolfi. 2003. The proportion of immature breeders as a reliable early warning signal of population decline: Evidence from the Spanish Imperial Eagle in Doñana. Biological Conservation 114:463-466.

Forero, M. G., J. A. Donázar, J. Blas, and F. Hiraldo. 1999. Causes and consequences of territory change and breeding dispersal distance in the Black Kite. Ecology 80:1298-1310.

Greenwood, P. J., And P. H. Harvey. 1982. The natal and breeding dispersal of birds. Annual Review of Ecology and Systematics 13:1-21.

Hénaux, V., T. Bregnballe, And J.-D. Lebreton. 2007. Dispersal and recruitment during population growth in a colonial bird, the Great Cormorant Phalacrocorax carbo sinensis. Journal of Avian Biology 38:44-57.

Kenward, R. E., S. P. Rushton, C. M. Perrins, D. W. MacDonALD, AND A. B. South. 2002. From marking to modelling: Dispersal study techniques for land vertebrates. Pages 50-71 in Dispersal Ecology (J. M. Bullock, R. E. Kenward, and R. S. Hails, Eds.). Blackwell, Oxford, United Kingdom.

Kenward, R. E., S. S. Walls, K. H. Hodder, M. Pahkala, S. N. Freeman, AND V. R. Simpson. 2000. The prevalence of nonbreeders in raptor populations: Evidence from rings, radio-tags and transect surveys. Oikos 91:271-279.

KORPIMÄKI, E., AND J. WIEHN. 1998. Clutch size of kestrels: Seasonal decline and experimental evidence for food limitation under fluctuating food conditions. Oikos 83:259-272.

KRÜGER, O. 2007. Long-term demographic analysis in goshawk Accipiter gentilis: The role of density dependence and stochasticity. Oecologia 152:459-471.

Lahaye, W. S., R. J. GutiérRez, And J. R. Dunk. 2001. Natal dispersal of the Spotted Owl in southern California: Dispersal profile of an insular population. Condor 103:691-700.

Lemon, J., AND B. Bolker. 2009. The plotrix Package: Various plotting functions. R package, version 2.5-4. [Online.] Available at cran.r-project.org/web/packages/plotrix/plotrix.pdf.

Mañosa, S., J. REAL, AND J. Codina. 1998. Selection of settlement areas by juvenile Bonelli's Eagle in Catalonia. Journal of Raptor Research 32:208-214.

Margalida, A., J. A. Donázar, J. Bustamante, F. J. Hernández, And M. Romero-Pujante. 2008. Application of a predictive model to detect long-term changes in nest-site selection in the Bearded Vulture Gypaetus barbatus: Conservation in relation to territory shrinkage. Ibis 150:242-249.

Matthysen, E. 2005. Density-dependent dispersal in birds and mammals. Ecography 28:403-416.

McCullagh, P., AND J. A. Nelder. 1983. Generalised Linear Modelling. Chapman \& Hall, London.

MirA, S. 2006. Population genetics of an endangered species, the Bonelli's Eagle (Hieraaetus fasciatus). Ph.D. dissertation, Universidade do Algarve, Faro, Portugal.

Muller, K. L., J. A. Stamps, V. V. Krishnan, and N. H. Willits. 1997. The effects of conspecific attraction and habitat quality on habitat selection in territorial birds (Troglodytes aedon). American Naturalist 150:650-661.

Müller, M., G. Pasinelli, K. Schiegg, R. SpaAr, and L. Jenni. 2005. Ecological and social effects on reproduction and local recruitment in the Red-backed Shrike. Oecologia 143:37-50.

Negro, J. J., F. Hiraldo, And J. A. Donázar. 1997. Causes of natal dispersal in the Lesser Kestrel: Inbreeding avoidance or resource competition? Journal of Animal Ecology 66:640-648.

Newton, I. 1979. Population ecology of raptors. T. \& A.D. Poyser, Berkhamsted, United Kingdom.

Newton, I. 1989. Sparrowhawk. Pages 279-296 in Lifetime Reproduction in Birds (I. Newton, Ed.). Academic Press, London.

Newton, I. 1992. Experiments on the limitation of bird numbers by territorial behaviour. Biological Reviews 67:129-173.

New TON, I. 1998. The role of the individual bird and the individual territory in the population biology of sparrowhawks Accipiter nisus. Pages 117-129 in Holartic Birds of Prey (R. D. Chancellor, B.-U. Meyburg, and J. J. Ferrero, Eds.). ADENEX-WWGBP, Merida, Spain.

Ontiveros, D., J. Real, J. Balbontin, M. R. Carrete, E. Ferreiro, M. Ferrer, S. Mañosa, J. M. Pleguezuelos, and J. A. SÁnCHEZ-ZAPATA. 2004. Conservation biology of the Bonelli's Eagle in Spain: Research and management. Ardeola 51:461-470.

Oro, D., AND R. Pradel. 2000. Determinants of local recruitment in a growing colony of Audouin's Gull. Journal of Animal Ecology 69:119-132.

PRADEL, R. 1996. Utilization of capture-mark-recapture for the study of recruitment and population growth rate. Biometrics 52:703-709.

Pradel, R., A. R. Johnson, A. Viallefont, R. G. Nager, and F. CÉZILLY. 1997. Local recruitment in the Greater Flamingo: A new approach using capture-mark-recapture data. Ecology 78:1431-1445.

R Development Core Team. 2007. R: A language and environment for statistical computing, reference index version 2.6.1. $\mathrm{R}$ Foundation for Statistical Computing, Vienna. [Online.] Available at www.R-project.org.

REAL, J. 2004. Aguila azor-perdicera, Hieraaetus fasciatus. In Libro Rojo de las Aves de España (A. Madroño, C. González, and J. C. Atienza, Eds.). Dirección General para la Biodiversidad-SEO/ Birdlife, Madrid.

Real, J., And S. Mañosa. 1997. Demography and conservation of western European Bonelli's Eagle Hieraaetus fasciatus populations. Biological Conservation 79:59-66.

Real, J., AND S. Mañosa. 2001. Dispersal of juvenile and immature Bonelli's Eagles in northeastern Spain. Journal of Raptor Research 35:9-14. 
Real, J., A. Tintó, A. Borau, A. Beneyto, and X. Parellada. 2004. Àliga perdiguera Hieraaetus fasciatus. In Atles dels Ocells Nidificants de Catalunya (1999-2002) (J. Estrada, V. Pedrocchi, L. Brotons, and S. Herrando, Eds.). Institut Català d'Ornitologia and Lynx Edicions, Barcelona, Spain.

Ringsby, T. H., B.-E. SÆther, H. Jensen, and S. Engen. 2006. Demographic characteristics of extinction in a small, insular population of House Sparrows in northern Norway. Conservation Biology 20:1761-1767.

Rocamora, G. 1994. Bonelli's Eagle Hieraaetus fasciatus. Pages 184-185 in Birds in Europe: Their Conservation Status (G. M. Tucker and M. F. Heath, Eds.). BirdLife Conservation Series, no. 3. BirdLife International, Cambridge, United Kingdom.

Roff, D. A. 1992. The Evolution of Life Histories: Theory and Analysis. Chapman \& Hall, London.

Rutz, C., And R. G. Bijlsma. 2006. Food-limitation in a generalist predator. Proceedings of the Royal Society of London, Series B 273:2069-2076.

SAino, N., S. CAlzA, AND A. P. Møller. 1997. Immunocompetence of nestling Barn Swallows in relation to brood size and parental effort. Journal of Animal Ecology 66:827-836.

Sedinger, J. S., And N. D. Chelgren. 2007. Survival and breeding advantages of larger Black Brant (Branta bernicla nigricans) goslings: Within- and among-cohort variation. Auk 124:1281-1293.
SERGio, F., AND I. Newton. 2003. Occupancy as a measure of territory quality. Journal of Animal Ecology 72:857-865.

Serrano, D., J. L. Tella, J. A. Donázar, and M. Pomarol. 2003. Social and individual features affecting natal dispersal in the colonial Lesser Kestrel. Ecology 84:3044-3054.

Sharp, S. P., M. B. Baker, J. D. Hadfield, M. Simeoni, And B. J. Hatchwell. 2008. Natal dispersal and recruitment in a cooperatively breeding bird. Oikos 117:1371-1379.

SOUTUllo, A., P. LóPEZ-López, AND V. URIOS. 2008. Incorporating spatial structure and stochasticity in endangered Bonelli's Eagle's population models: Implications for conservation and management. Biological Conservation 141:1013-1020.

Tavecchia, G., R. Pradel, M. Genovart, and D. Oro. 2007. Density-dependent parameters and demographic equilibrium in open populations. Oikos 116:1481-1492.

Tella, J. L., G. R. Bortolotti, R. D. Dawson, and M. G. Forero. 2000. The T-cell-mediated immune response and return rate of fledgling American Kestrels are positively correlated with parental clutch size. Proceedings of the Royal Society of London, Series B 267:891-895.

Associate Editor: M. Bechard 